The pathogenesis of the syndrome is discussed and evidence for an abnormality of extracellular fluid volume control is presented.

We wish to acknowledge the invaluable assistance of the Metabolic Unit Staff at the Los Angeles County General Hospital in studies of this patient.

\section{REFERENCES}

Ames, R. P., Borkowski, A. J., Sicinski, A. M., and Laragh, J. H. (1965).

B. clin. Invest., 44, 1171, Amer. F. Med., 33, 811.

Boucher, R., Veyrat, R., Champlain, J. de, and Genest, J. (1964). Canad. med. Ass. Y., 90, 194 .

Brown, J. J., Davies, D. L., Lever, A. F., and Robertson, J. I. S. (1964), f. Physiol. (Lond.), 173, 408 .

Bryan, G. T., MacCardle, R. C., and Bartter, F. C. (1966). Pediatrics, 37, 43.
Cannon, P. J., Ames, R. P., and Laragh, J. H. (1964). F. clin. Invest.. 43, 1294 .

Fasciolo, J. C., De Vito, E., Romero, J. C., and Cucchi, J. N. (1964). Canad. med. Ass. F., 90, 206.

Gann, D. S., Delea, C. S., Gill, J. R., Thomas, J. P., and Bartter, F. C. (1964). Amer. F. Physiol., 207, 104.

Genest, I. et al. (1964). In Aldosterone. A Symposium, edited by B. Baulieu and F. Robel, pp. 393-414. Oxford.

Goldblatt, H., Lynch, J., Hanzal, R. F., and Summerville, W. W. (1934). f. exp. Med., 59, 347.

Hocken, A. G., and Kark, R. M. (1965). Lancet, 2, 988.

Kaplan, N. M., and Silah, J. G. (1964). '. clin. Invest., 43, 659.

Laragh, J. H., and Kelly, W. G. (1964). In Advances in Metabolic Disorders, edited by R. Levine and R. Luft, vol. 1, p. 242. New York

Luetscher, J. A. (1956). Recent Progr. Hormone Res., 12, 175.

Nelson D. H., and August, J. T. (1959). Lancet, 2, 883.

Peart, W. S. (1965). Pharmacol. Rev. 17, 143.

Pickering, G. W., and Prinzmetal, M. (1940). f. Physiol. (Lond.), 98, 314 .

Pronove, P., MacCardle, R. C., and Bartter, F. C. (1960). Acta endocr. (Kbh.), Suppl. No. 51, p. 167.

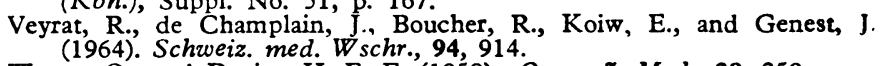

Wrong, O., and Davies, H. E. F. (1959). Quart. 7. Med., 28, 259.

\title{
Total Parathyroidectomy in Treatment of Secondary (Renal) Hyperparathyroidism
}

\author{
C. S. OGG,* M.B., B.SC., M.R.C.P.
}

Recent improvements in the care of patients with chronic renal failure have revealed that symptoms attributable to renal glomerular (uraemic) osteodystrophy develop in a considerable number of cases.

The various components of this bone disease include rickets or osteomalacia, osteitis fibrosa, and osteosclerosis. These may occur in almost pure forms but more commonly appear in varying combinations in different patients.

Treatment with large doses of vitamin D ( Liu and Chu, 1943 ; Dent et al., 1961 ; Stanbury and Lumb, 1962) is often successful in promoting healing of the skeleton, but is dangerous because of the ease with which it is possible to produce hypercalcaemia and metastatic calcification. This danger is greatest in those patients who have osteitis fibrosa as the dominant skeletal lesion, and who, unlike the majority of patients with renal failure who have low plasma calcium levels (de Wesselow, 1923), have plasma calcium levels that are either within the normal range (Stanbury and Lumb, 1966) or even frankly raised (Hubbard and Wentworth, 1921 ; Smyth and Goldman, 1934 ; Shelling and Remsen, 1935).

Stanbury et al. (1960) were the first to embark deliberately on a policy of subtotal parathyroidectomy in a patient with severe secondary hyperparathyroidism, and they were subsequently able to heal the bone lesions with vitamin $\mathrm{D}$ without producing hypercalcaemia. Since then further reports have appeared in this country (Findley et al., 1961), in South Africa (Stables et al., 1964), and in the United States of America (Anderson et al., 1963 ; Fordham and Williams, 1963 ; Golden et al., 1965 ; Felts et al., 1965 ; Wilson et al., 1965). These reports include a total of only 12 cases, and it is considered worth while to report four more.

\section{Case 1}

A 43-year-old man presented in 1961 with severe chronic renal failure (plasma urea $210 \mathrm{mg} . / 100 \mathrm{ml}$.). No cause for this was found, and he was treated with a high fluid intake, a low protein diet, and sodium bicarbonate $2 \mathrm{~g}$. daily.
During the following year he developed radiological changes of hyperparathyroidism in his hands, but this caused no symptoms until 1964, when he felt severe pain in both shoulders. His plasma calcium had risen to $10.5 \mathrm{mg} . / 100 \mathrm{ml}$. (Fig. 1), with an ionized fraction of $5.0 \mathrm{mg} . / 100 \mathrm{ml}$. and a complexed fraction of $1.3 \mathrm{mg}$./ $100 \mathrm{ml}$. (normal range $4.9-5.8$ and $0.0-0.7 \mathrm{mg} . / 100 \mathrm{ml}$. respectively (L. Watson, personal communication, 1967). $X$-ray films showed progression of the subperiosteal erosions of the phalanges and the appearance of erosions of the lateral ends of both clavicles.

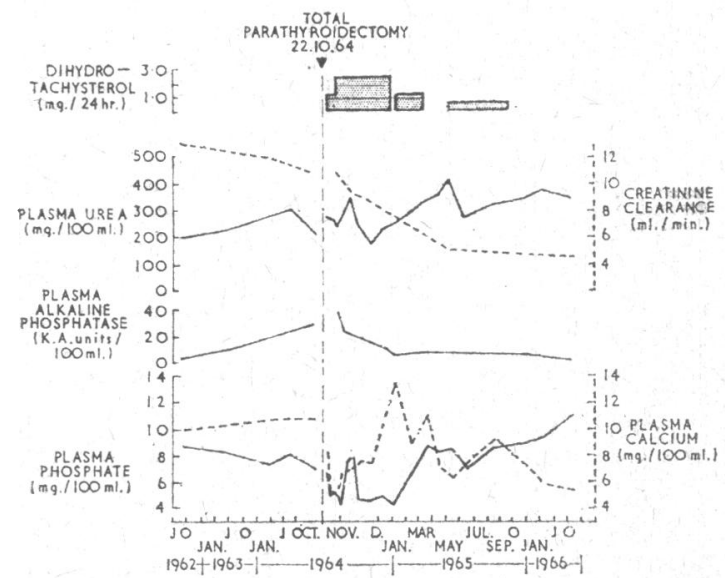

FIG. 1.-Case 1. Biochemical progress. Note changing time scale.

It was also noted that there was a considerable amount of calcification in the internal iliac arteries. Because of the metastatic calcification total parathyroidectomy was recommended, and four hyperplastic glands were removed. Preoperative and postoperative findings are shown in Tables I and II.

The plasma calcium fell to a minimum of $4.9 \mathrm{mg} . / 100 \mathrm{ml}$. on the fifth postoperative day, and symptoms of tetany were controlled with intravenous calcium gluconate and oral dihydrotachysterol. Within a month he had lost his bone pain and was discharged

* Medical Registrar, St. Peter's, St. Paul's, and St. Philip's Hospitals, London W.C.2. Present address: Renal Unit, Guy's Hospital, London S.E.1. 
TABLE I.-Status of Patients Immediately before Surgery

\begin{tabular}{|c|c|c|c|c|c|c|c|c|c|c|c|c|}
\hline \multirow{3}{*}{$\begin{array}{l}\text { Case } \\
\text { No. }\end{array}$} & \multirow{3}{*}{$\begin{array}{l}\text { Renal } \\
\text { Lesion }\end{array}$} & \multirow{3}{*}{ B.P. } & \multirow{2}{*}{\multicolumn{2}{|c|}{ Years of }} & \multirow{3}{*}{$\begin{array}{c}\text { Previous } \\
\text { Vitamin D }\end{array}$} & \multirow{3}{*}{$\begin{array}{l}\text { Creatinine } \\
\text { Clearance } \\
\text { (ml./min.) }\end{array}$} & \multicolumn{5}{|c|}{ Plasma } & \multirow{3}{*}{$\underset{\text { Urine }}{\text { Calsium }}$} \\
\hline & & & & & & & \multirow{2}{*}{$\underset{\text { (mg./100 ml.) }}{\text { Urea }}$} & \multicolumn{2}{|c|}{$\begin{array}{c}\text { Calcium } \\
\text { (mg./100 ml.) }\end{array}$} & \multirow{2}{*}{$\begin{array}{l}\text { Phosphate } \\
\text { (mg./100 ml.) }\end{array}$} & \multirow{2}{*}{$\begin{array}{c}\text { Alkaline } \\
\text { Phosphatase } \\
\text { (K.A. Units/ } \\
100 \text { ml.) }\end{array}$} & \\
\hline & & & $\begin{array}{c}\text { Renal } \\
\text { Lesion }\end{array}$ & $\begin{array}{c}\text { Bone } \\
\text { Lesion }\end{array}$ & & & & Total & Ionized & & & \\
\hline \multirow{3}{*}{$\begin{array}{l}1 \\
2 \\
3 \\
4\end{array}$} & \multirow{3}{*}{$\begin{array}{l}\text { Unknown } \\
\text { Bladder neck } \\
\text { obstruction } \\
\text { Chronic glomerulo- } \\
\text { nephritis } \\
\text { ? Dysplasia }\end{array}$} & $130 / 80$ & $>3$ & 2 & No & $10 \cdot 0$ & 205 & 10.5 & $5 \cdot 0$ & 6.8 & 22 & 152 \\
\hline & & $120 / 80$ & 14 & $>3$ & Yes & $5 \cdot 0$ & 210 & $11 \cdot 3$ & 5.7 & $7 \cdot 8$ & 28 & 123 \\
\hline & & $\begin{array}{l}165 / 100 \\
140 / 90\end{array}$ & $\begin{array}{r}29 \\
>2\end{array}$ & $>\stackrel{?}{1.5}$ & $\begin{array}{c}\text { No } \\
\text { " }\end{array}$ & $\begin{array}{l}8.4 \\
3.0\end{array}$ & $\begin{array}{l}125 \\
280\end{array}$ & $\begin{array}{l}11 \cdot 1 \\
10 \cdot 2\end{array}$ & $\begin{array}{l}6.0 \\
5.6\end{array}$ & $\begin{array}{r}5.9 \\
10 \cdot 0\end{array}$ & $\begin{array}{l}40 \\
42\end{array}$ & $\begin{array}{r}110 \\
72\end{array}$ \\
\hline
\end{tabular}

from hospital taking oral dihydrotachysterol and calcium supplements. The doses of these were reduced until they were stopped in September 1965.

His renal disease continued to progress, but at the time of writing he was still working full time.

\section{Case 2}

In 1961 an 11-year-old boy had a urinary tract infection. Investigation revealed moderate renal failure (blood urea $91 \mathrm{mg} . /$ $100 \mathrm{ml}$.) and bladder-neck obstruction with ureteric dilatation. Despite relief of the obstruction his blood urea remained raised, and he continued to have episodes of infection.

Two years later he first had pains in his legs, and in 1964 he was referred for further investigation. The presence of severe renal failure (blood urea $237 \mathrm{mg} . / 100 \mathrm{ml}$.), together with a urinary infection, was confirmed. Plasma calcium was $10.3 \mathrm{mg} . / 100 \mathrm{ml}$.,

TABLE II.-Summary of Operative Findings and Postoperative Course

\begin{tabular}{|c|c|c|c|c|c|}
\hline $\begin{array}{l}\text { Case } \\
\text { No. }\end{array}$ & $\begin{array}{l}\text { Date of } \\
\text { Operation }\end{array}$ & $\begin{array}{l}\text { No. of } \\
\text { Glands }\end{array}$ & $\begin{array}{c}\text { Weight of } \\
\text { Glands } \\
\text { (g.) }\end{array}$ & $\begin{array}{l}\text { Postoperative } \\
\text { Therapy }\end{array}$ & $\begin{array}{l}\text { Survival } \\
\text { (Months) }\end{array}$ \\
\hline 1 & $22 / 10 / 64$ & 4 & 1.46 & $\begin{array}{c}10 \% \text { Ca gluconate } 40 \mathrm{ml} . \\
\text { Dihydrotachysterol }\end{array}$ & $>32$ \\
\hline 2 & $20 / 1 / 66$ & 4 & 2.53 & $\begin{array}{l}10 \% \text { Ca gluconate } 40 \mathrm{ml} . \\
\text { Dihyddotachysterol } \\
8 \text { mg. Parathyroid } \\
\text { hormone } 4 \mathrm{ml} \text {. }\end{array}$ & n \\
\hline $\begin{array}{l}3 \\
4\end{array}$ & $\begin{array}{l}30 / 5 / 63 \\
20 / 6 / 63\end{array}$ & $\begin{array}{l}2 \\
4\end{array}$ & $\begin{array}{l}2.68 \\
2.15\end{array}$ & $\begin{array}{l}\text { Calciferol } 1.25 \mathrm{mg} \text {. alt. die } \\
\text { Dihydrotachysterol } 5 \mathrm{mg} \text {. }\end{array}$ & $\begin{array}{l}9 \\
0.1\end{array}$ \\
\hline
\end{tabular}



FIG. 3

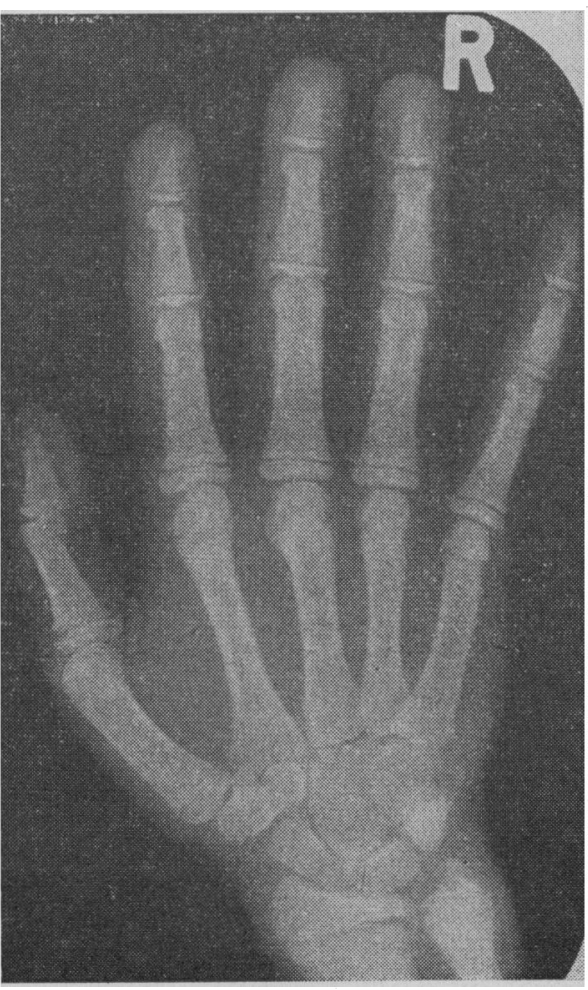

Fig. 4

and there was gross elevation of the plasma alkaline phosphatase (84 K.A. units/100 ml.) (Fig. 2). A radiological skeletal survey showed epiphysial changes suggestive of rickets, together with subperiosteal erosions on the phalanges, resorption of the phalangeal tufts (Figs. 3 and 6), erosion of the lateral ends of the clavicles, and a "rugger jersey" spine. Dietary protein restriction, antibiotics, and a high fluid intake led to a fall in blood urea but did not affect his skeletal symptoms. The addition of calciferol resulted in clinical and radiological improvement, but was associated with hypercalcaemia (11.6 mg./100 ml.), which persisted despite

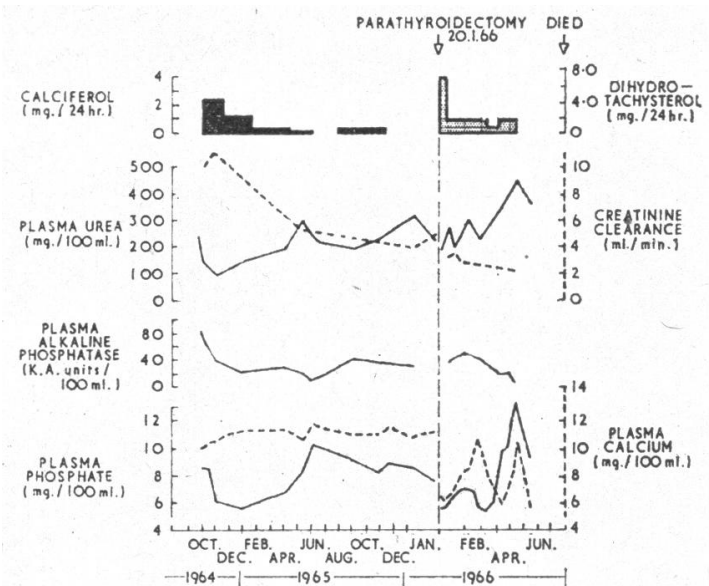

Fig. 2.-Case 2. Biochemical progress. Note changing time scale.

Fig. 3.-Case 2. $X$-ray film of right hand, 2 October 1964. Fig. 4.-Case 2. X-ray film of right hand, 6 January 1966. Fig. 5.-Case 2. $X$-ray film of right hand, 30 March 1966. 
reduction of dosage and eventual cessation of treatment in November 1965. By this stage his symptoms had returned, and when reassessed in January 1966 he was incapacitated by pain in his legs and had developed a waddling gait. His renal function had deteriorated, and $x$-ray films showed that the changes of secondary hyperparathyroidism had become more pronounced, while the changes suggesting rickets had if anything regressed (Figs. 4 and 6). Plasma calcium fractionation showed an ionized fraction of $5.7 \mathrm{mg} . / 100 \mathrm{ml}$ (Table I) and a complexed fraction of $1.4 \mathrm{mg} . / 100 \mathrm{ml}$. Total parathyroidectomy was advised, and four hyperplastic glands were removed.

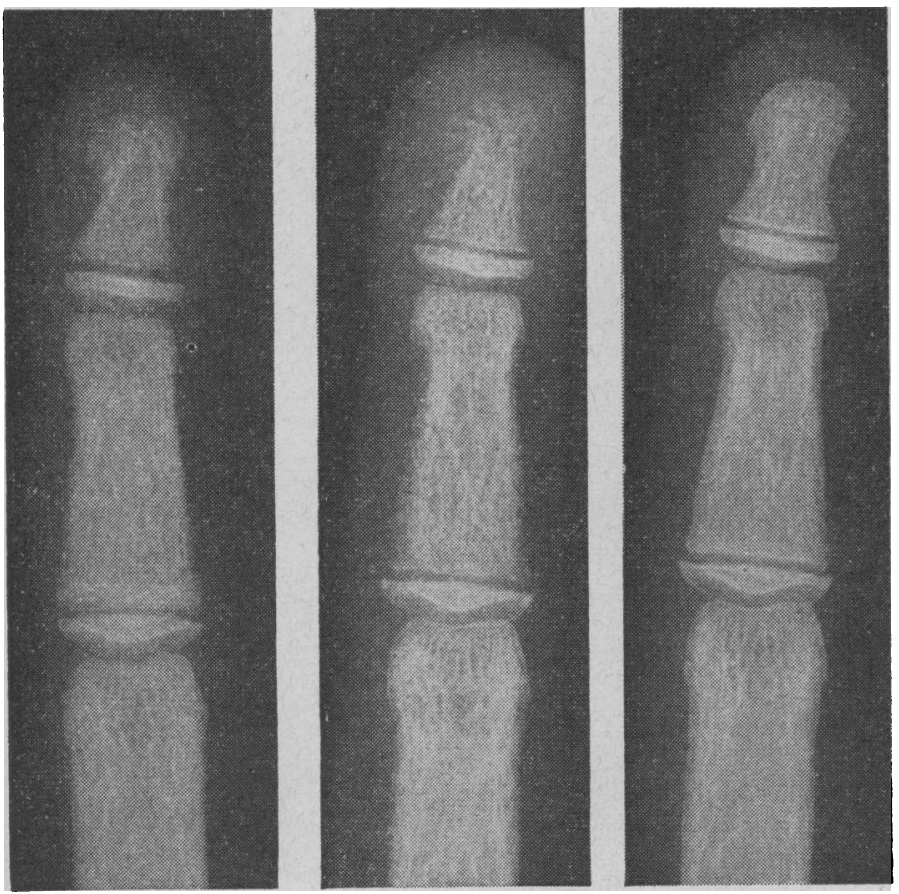

FIG. 6.-Case 2. $X$-ray films of right muddle finger. Left, 2 October 1964. Centre, 6 January 1966. Right, 30 March 1966.

Postoperatively he developed severe hyperkalaemia $(8.7 \mathrm{mEq} / 1$.) but responded to conservative treatment for this. Within 24 hours the plasma calcium fell to $6.2 \mathrm{mg} . / 100 \mathrm{ml}$. ; subsequently it was maintained at this level, with intravenous calcium gluconate, intramuscular parathyroid hormone, and oral dihydrotachysterol (Table II). Four days later treatment was reduced to oral dihydrotachysterol with a calcium supplement. His bone pain disappeared within three weeks, and two weeks later there was obvious radiological improvement (Figs. 5 and 6). The dose of dihydrotachysterol was reduced, being finally stopped in April.

Unfortunately his renal function continued to deteriorate, but he remained free of bone pain until his death in July 1966. Necropsy was not performed.

\section{Case 3}

A 42-year-old woman had had acute nephritis at the age of 13 , and in 1953 she was seen with proteinuria and a raised blood urea (70 mg./100 ml.). Ten years later she was referred because of progressive deterioration in renal function (blood urea $125 \mathrm{mg} . /$ $100 \mathrm{ml}$.). Routine skeletal survey revealed changes of hyperparathyroidism with erosion of the borders of the phalanges and of the phalangeal tufts. Her plasma calcium was $11.1 \mathrm{mg} . / 100 \mathrm{ml}$. (ionized fraction $6.0 \mathrm{mg} . / 100 \mathrm{ml}$., complexed fraction $1.3 \mathrm{mg} . /$ $100 \mathrm{ml}$.) with a plasma alkaline phosphatase of $40 \mathrm{~K}$.A. units/ $100 \mathrm{ml}$. (Table I). At parathyroid exploration only two glands could be identified (Table II). Both were enlarged, but one $(2.51 \mathrm{~g}$. was much larger than the other $(0.17 \mathrm{~g}$.). Despite this the histological appearances were thought to favour a diagnosis of secondary hyperplasia rather than of adenoma. Within 24 hours the plasma calcium and phosphate fell to 7.0 and $3.9 \mathrm{mg} . / 100 \mathrm{ml}$. respectively. Calciferol $1.25 \mathrm{mg}$. on alternate days was started, and two weeks later she was discharged from hospital.

Subsequently, though there was radiological evidence of improvement of the bone lesions, her renal function continued to deteriorate until her death nine months later. Necropsy revealed granular contracted kidneys compatible with the diagnosis of chronic glomerulonephritis.

\section{Case 4}

A 14-year-old girl presented in February 1962 with chronic renal failure (plasma urea $170 \mathrm{mg} . / 100 \mathrm{ml}$.). Investigations revealed a solitary contracted right kidney and radiological evidence of hyperparathyroidism with erosion of the borders of the phalanges. She was treated with a high fluid intake, moderate protein restriction, and sodium bicarbonate $3 \mathrm{~g}$. daily.

Fifteen months later she first complained of pain in the shoulders and legs. Further $x$-ray films revealed progression of the bone disease with severe changes in the hands, clavicles, and skull. There was extensive arterial calcification with metastatic deposits of calcium adjacent to several interphalangeal joints. Her renal function had deteriorated further, and the plasma calcium had risen to $10.2 \mathrm{mg}$./ $100 \mathrm{ml}$. (ionized fraction $5.6 \mathrm{mg} . / 100 \mathrm{ml}$., complexed fraction $0.8 \mathrm{mg} . / 100 \mathrm{ml}$.), with a plasma alkaline phosphatase of $42 \mathrm{~K}$.A. units/100 ml. (Table I). Parathyroidectomy was advised, and four hyperplastic glands were removed (Table II). Postoperatively, continued haemorrhage necessitated re-exploration and drainage of the wound. Her plasma calcium and phosphate fell to 5.6 and $6.3 \mathrm{mg} . / 100 \mathrm{ml}$. respectively on the third day. That evening she died unexpectedly, and subsequently her plasma potassium was found to have risen to $7.9 \mathrm{mEq} / \mathrm{l}$.

\section{Discussion}

It is apparent that parathyroidectomy and subsequent treatment with large doses of vitamin D may allow healing of the bone lesions of secondary (renal) hyperparathyroidism without inducing hypercalcaemia. Once the bone lesions have healed the amount of vitamin $D$ required to keep the patients free of symptoms attributable to hypocalcaemia may diminish, and in two of the cases it was possible to withdraw vitamin D altogether.

The operations did not influence the progress of the primary renal disease. In Cases 2 and 3 they were clearly performed too late to be of any great value to the patients. Case 1, however, experienced considerable benefit, and in retrospect it would seem that earlier operation in Case 2 might have saved the patient months of invalidism.

The progress (Figs. 3, 4, and 6) of the bone disease in Case 2 during the initial phase of treatment with vitamin D seems to contradict the view that hyperparathyroidism develops secondarily to the calcification defect of renal glomerular osteodystrophy. In these circumstances one might have expected the osteitis fibrosa to heal when the rickets was treated. However, the hyperparathyroidism which is commonly associated with osteomalacia of dietary origin, and which usually remits when the latter is treated, may occasionally become autonomous (Davies et al., 1956). There is evidence that this may happen in patients with secondary (renal) hyperparathyroidism, for at least six patients have been subjected to parathyroidectomy only after successful renal transplantation had revealed the classical biochemical findings usually associated with primary hyperparathyroidism (McPhaul et al., 1964 ; Wilson et al., 1965 ; McIntosh et al., 1966). In each case four enlarged glands were found.

Most patients with renal failure have low plasma ionized calcium levels (Fanconi and Rose, 1958 ; Walser, 1962), and the finding of a raised (Case 3 ) or high normal (Cases 2 and 4) level suggests that parathyroid autonomy has developed and is a strong indication for parathyroidectomy. Less definite indications include the presence of metastatic calcification and the failure of treatment with vitamin $\mathrm{D}$ to heal the skeleton without inducing hypercalcaemia.

In order to avoid the possibility of recurrence of the hyperparathyroidism, total rather than subtotal parathyroidectomy was advised. In consequence the fall observed in the plasma 
calcium level was profound. This might be expected to sensitize the myocardium (Meroney and Herndon, 1954) to the rise in plasma potassium that may occur in any patient with renal failure who has had a major operation. This combination of events was presumably responsible for the death of Case 4. The postoperative fall in plasma phosphate is the opposite to what is seen in patients who have had a parathyroidectomy for primary hyperparathyroidism. This was found also by Stanbury et al. (1960), who pointed out that, as the normal phosphaturic effect of exogenous parathyroid hormone does not occur in the presence of a reduction in creatinine clearance to less than $10 \mathrm{ml} . /$ minute (Goldman and Bassett, 1954), parathyroidectomy would not be expected to change the renal phosphate clearance. Though the urinary excretion of phosphate fell postoperatively in all the patients, the fall was no greater than would be expected from that in the plasma level, and presumably the fall in the plasma level is due to the deposition of phosphate with calcium in bone.

The practical problems imposed by the appearance of autonomous hyperparathyroidism after successful renal transplantation are considerable. At least one transplanted kidney has been affected by calculi associated with autonomous (secondary) hyperparathyroidism (Hume et al., 1966), and in any case the dangers of parathyroidectomy must be increased considerably by the immunosuppressive and steroid therapy that these patients receive. Thus if the presence of hyperparathyroidism is recognized it is probably advisable to deal with it before embarking upon transplantation.

\section{Summary}

Previous experience of the use of parathyroidectomy in the treatment of secondary (renal) hyperparathyroidism has been reviewed briefly. Four further cases are reported, and it is suggested that, with increasing interest in the management of chronic renal failure, the operation may be performed more often in the future than it has been in the past. The indications for and the timing of surgery are discussed.

I wish to thank Dr. A. M. Joekes and Dr. A. R. Harrison for permission to report these cases. Mr. J. D. Fergusson performed all the operations and Dr. L. Watson carried out the plasma calcium fractionations.

\section{REFERENCES}

Anderson, W. W., Mann, J. B., Kenyon, N., Farrell, J. J., and Hills, A. G. (1963). New Engl. ₹. Med., 268, 575

Ball, J. (1960). In Recent Advances in Pathology, 7th ed., edited by C. V. Harrison. London.

Davies, D. R., Dent, C. E., and Willcox, A. (1956). Brit. med. Y., 2, 1133 .

de Wesselow, O. L. V. (1923). Ibid., 16, 341.

Dent, C. E., Harper, C. M., and Philpott, G. R. (1961). Quart. F. Med., 30, 1., A., and Rose, G. A. (1958). Ibid., 27, 463.

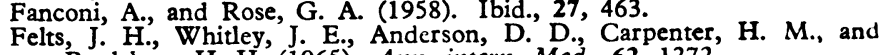
Bradshaw, H. H. (1965). Ann. intern. Med., 62, 1272 .

Findley, T., Moore, J. D., and Brackney, E. L. (1961). Lancet, 2, 1150. Fordham, C. C., and Williams, T. F. (1963). New Engl. J. Med., 269,

129.
Gilmour, J. R. (1947). The Parathyroid Glands and Skeleton in Renal Disease. London.

Golden, A., Canary, J. J., and Kerwin, D. M. (1965). Amer. F. Med., 38, 562.

Goldman, R., and Bassett, S. H. (1954). F. clin. Invest., 33, 1623.

Hubbard, R. S., and Wentworth, J. A. (1921). Proc. Soc. exp. Biol (N.Y.), 18, 307

Hume, D. M., et al. (1966). Ann. Surg., 164, 352.

Liu, S. H., and Chu, H. I. (1943). Medicine (Baltimore), 22, 103.

McIntosh, D. A., Peterson, E. W., and McPhaul, J. J. (1966). Ann. intern. Med., 65, 900.

McPhaul, J. J., McIntosh, D. A., Hammond, W. S., and Park, O. K. (1964). New Engl. 7. Med., 271, 1342. Meroney, W. H., and Herndon, R. F. (1954). F. Amer. med. Ass., 155 ,

877.

Shelling, D. H., and Remsen, D. (1935). Bull. Johns Hopk. Hosp., 57. 158.

Smyth, F. S., and Goldman, L. (1934). Amer. F. Dis. Child., 48, 596.

Stables, D. P., Levin, N. W., Rubenstein, A. H., Berk, M. E., and Abrahams, C. (1964). Ann. intern. Med., 61, 531.

Stanbury, S. W., and Lumb, G. A. (1962). Medicine (Baltimore), 41, 1. (1966). Quart. I Med., 35, 1 .

二- (1966) Nicholson, W. F. (1960). Lancet, 1, 793.

Walser, M. (1962). F. clin. Invest., 41, 1454.

Wilson, R. E., Bernstein, D. S., Murray, J. E., and Moore, F. D. (1965) Amer. F. Surg., 110, 384.

\title{
Syndrome of Sclerodactyly, Calcinosis, Raynaud's Phenomenon, and Telangiectasia
}

\author{
A. W. DELLIPIANI,* M.B., M.R.C.P.ED. ; M. GEORGE, † M.B., B.SC., M.R.C.P., M.R.C.P.ED.
}

Brit. med. F., 1967, 4, 334-335

Since Thibierge and Weissenbach (1911) described the association between scleroderma and calcinosis the ThibiergeWeissenbach syndrome has come to mean anything from progressive systemic sclerosis with calcinosis (Durham, 1928) to a much more benign syndrome in which sclerodactyly, calcinosis, and Raynaud's phenomenon are associated with telangiectasia (Prosser Thomas, 1942). In the 10 years preceding 1964 only 18 cases with this clearly defined syndrome had been reported, and to these Winterbauer (1964) added another seven. The present report describes three further cases and reviews the prognosis in this syndrome.

\section{Case 1}

A 66-year-old woman gave a history of Raynaud's phenomenon in the hands since the age of 20 , which had been more of an inconvenience than a disability. The most recent admission was caused by an exacerbation of dyspnoea, which had been present for * Department of Therapeutics, the Royal Infirmary, Edinburgh 3.
t Department of Cardiology, the Royal Infirmary, Edinburgh 3. two to three years. There was no family history of telangiectasia or of recurrent haemorrhagic episodes to suggest this.

Some rheumatoid deformity was present in the hands, there was also sclerodactyly and a thickened subcutaneous plaque in the left forearm. Telangiectatic spots were present on the lips, the buccal mucosa, and the hands. Other abnormal findings were a raised jugular venous pressure and a cardiac apex in the sixth space outside the midclavicular line, the impulse being left ventricular in type. A mitral grade III regurgitant systolic murmur was audible at the apex with a third heart sound. Marked dorsal kyphosis was present, and the liver was enlarged one fingerbreadth and was soft.

The abnormal findings on investigation were that the chest $x$-ray film showed left ventricular enlargement with pulmonary congestion. Radiographs of the hands showed contractures of the thumbs and fifth fingers of both hands with soft-tissue calcification in the fingers (see Fig.). Respiratory function tests demonstrated impaired vital capacity $(1,350 \mathrm{ml}$.; predicted $1,900 \mathrm{ml}$.) with increased residual volume $(2,460 \mathrm{ml}$; predicted 1,800 ml.). There was evidence of obstructive airway disease, the ratio F.E.V.1/F.V.C. being $56 \%$. $\mathrm{O}_{2}$ saturation was $86 \% ; \mathrm{PcO}_{2} 38 \mathrm{~mm}$. $\mathrm{Hg} ; \mathrm{pH} 7.40$. The findings were thought to be compatible with the presence of pulmonary congestion and kyphoscoliosis. 